\title{
Relationships Between Human Attributes and Sources of Information for Seeking Halal Food Information: A Pilot Research on Kuala Lumpur, Malaysia
}

\author{
Firas Saleh Omari, Norhidayah Azman, Roesnita Ismail
}

\begin{abstract}
This paper aims at investigating the impacts between information sources used and human attributes, namely: Attitude, Habit and Awareness of Individual in seeking for information about halal food products effectively among Malaysian Muslim consumers in Kuala Lumpur. This study was conducted to address the following research questions: 1) Are there any relationships between the use of different information sources and Attitude that might positively relate to the perception of wholesomeness, leading to effective seeking for halal food information?; 2) Are there any relationships between the use of different information sources and Habit that might positively relate to the perception of wholesomeness, leading to effective searching for halal food information?; and 3) Are there any relationships between the use of different information sources and Awareness of individuals that might positively relate to the perception of wholesomeness, leading to effective searching for halal food information? A pilot study was conducted in Kuala Lumpur, Malaysia, with a sample size of 50 respondents. Most of the respondents were young Malaysian Muslims between the ages of 18 and 24 years old. The data was gathered through a fivepoint Likert scale and was analysed quantitatively using SPSS. The findings of this study suggest that linking between information sources used by consumers, and the abovementioned human attributes will ensure the perception of wholesomeness of halal food. In other words, when the consumer's attitude, habit and awareness towards halal food are high, the consumer will use credible and trusted information sources, and hence reach an effective searching process for halal food information. Accordingly, this study provides insights into how Malaysian Muslim consumers seek information for halal food.
\end{abstract}

Index Terms: Effective information seeking, Halal food, Human attributes, Information sources.

\section{INTRODUCTION}

In order to understand the effects of linking between human attributes and information sources for effective halal food information seeking, it is important to identify factors impacting the choice of halal food products and to understand their effects on the selection behavior. This is in correspondence to [1], who said that texture, taste, variations, packaging, quality, affordability, freshness and price are the influencing factors that make halal food become the most significant choice in Muslim consumer preferences.

Revised Manuscript Received on July 18, 2019.

Firas Saleh Omari, Faculty of Science \& Technology, University Sains Islam Malaysia (USIM). (Email: firasomari2015@gmail.com)

Norhidayah Azman, Faculty of Science \& Technology, University Sains Islam Malaysia (USIM). (Email: dayah@usim.edu.my)

Roesnita Ismail, Faculty of Science \& Technology, University Sains Islam Malaysia (USIM). (Email: roesnita@usim.edu.my)
This study aims at reaching to the perception of wholesomeness of halal food products that covers permissible requirements of the law of Islam, and hence reaching to effective searching for halal food products. This aim was described by [2] where concepts of halal and Tayyib were defined by the wholesomeness of the food. Reference [3] has stated that due to the significance of wholesomeness for Muslims, the practices of total quality management TQM requires to be implemented for the aim of marketing halal productions as the food producer should not only concentrate on methods for halal certification. Hence, quality assurance and wholesomeness could increase the desire for such productions. Positively, Muslim consumers have given a growing response to halal, for it is a positive improvement in Islamic beliefs and practices [4]. Consequently, it is essential that halal food should meet quality and wholesomeness of produced food.

Extensive research and studies have been done in the field of information seeking behavior such as a professional model of information seeking for engineers, health care and lawyers by [5], [6], [7], and [8]. With that, a lot of information seeking behavior models have been improved for halal food products such as [9] and [10]. However, little research links the two types of models: human information behavior models and information seeking models. This research assumes that linking among human information attributes, namely: attitude, habit and awareness of individual and sources of information as an attribute of information seeking model may lead to an effective searching process, thus arriving to the perception of wholesomeness of halal food products among Malaysian Muslim consumers.

Malaysian Muslim consumers were examined on three different aspects related to information source selection behavior, namely: availability and reliability of information on halal food products, factors impacting the choice of halal food products and halal food products information sources. This study focused on how the linking between attitude, habit and awareness of Malaysian Muslim consumers with information sources attributes will lead to the perception of wholesomeness of the food products, and hence achieves an effective searching process for halal food products. 


\section{RELATIONSHIPS BETWEEN HUMAN ATTRIBUTES AND SOURCES OF INFORMATION FOR SEEKING HALAL FOOD INFORMATION: A PILOT RESEARCH ON KUALA LUMPUR, MALAYSIA}

Findings of this study will help in identifying key factors impacting the choice of halal food products and their influence on the source selection behavior for halal food products. Such knowledge will contribute in improving the searching process for halal food products through enhanced ability to teach customers the selection of the best source for halal food products.

This paper is organized as follows; the discussion of the related work regarding factors affecting information seeking behavior for halal food products, followed by research objectives, questions and hypotheses, and then survey details about the availability and the reliability of information about halal food products in the Malaysian Market, after that, data analysis and discussion of the findings and recommendations; and finally, conclusion is drawn and possible directions of future works are identified.

\section{RELATED STUDIES}

Previous studies have recently reported several related factors influencing information seeking behaviors for halal food productions concerning ingredients, awareness of an individual, habit, Islamic laws, and attitude. For example, [11] studied the ambiguity in determining the halal product due to the obstacles of the existing scenarios in the industry among 340 Muslims in Bangi, Selangor, Malaysia. The study instigated that awareness factor is significantly correlated with information seeking behavior among Muslim families. [12] identified the factors that impact the Malaysian youth Muslims' behavioral intent to consume halal food at the Private Higher Learning Institutions of Malaysia among consumers aged between 16 and 35 years old. The study uncovered that the intention to consume halal food in Klang Valley, Malaysia was often affected by the positive attitudes of young Muslims and their behavioral dominance towards halal food. Reference [13] proposed a model to limit the impact of religious commitment on halal brand relationship and buying intent. The highlighting point in that study is the usage of this model to define the effect of the halal brand relationship as intermediated between religiosity and buying intent. The influence of brand trust, brand attachment and brand commitment to make a significant relationship with consumers is regarded as a worthy stream in that research.

Though extensive research has been done in the field of information seeking behavior, little research still links the two types of models, namely: human information behavior models and information seeking models. This research is the first to link among human information attributes: attitude, habit and awareness of an individual, and sources of information as an attribute of information seeking model.

\section{RESEARCH OBJECTIVES, QUESTIONS AND HYPOTHESES}

\section{A. Research Objectives}

The main objective of this research is to investigate the effects of linking human attributes namely: attitude, habit and awareness of individual with information sources used in searching for halal food information effectively.

\section{B. Research Questions}

RQ1: Are there any relationships between the use of different information sources and attitude that might be related to the perception of wholesomeness which leads to effective seeking for halal food information?

RQ2: Are there any relationships between the use of different information sources and Habit that might be related to the perception of wholesomeness which leads to effective seeking for halal food information?

RQ3: Are there any relationships between the use of different information sources and awareness of the individual that might be related to the perception of wholesomeness which leads to effective seeking for halal food information?

\section{Research Hypotheses}

H1: A correlation between attitude and sources of information used exists, that is positively related to the perception of wholesomeness which leads to effective seeking for Halal food information.

$\mathrm{H} 2$ : A correlation between habit and sources of information used exists, that is positively related to the perception of wholesomeness which leads to effective seeking for Halal food information.

H3: A correlation between awareness of individual and sources of information used exists, that is positively related to the perception of wholesomeness which leads to effective seeking for Halal food information.

\section{METHOD}

A survey on the availability and the reliability of information about halal food products was conducted in Kuala Lumpur with the intention of answering the following research questions. The survey contained five sections:

Section A: Demographic information for respondents: Gender, age, education, occupation, residential area and monthly income. (6 questions)

Section B: Significance of halal food which describes the respondent's agreement level of human attributes, attitude, habit and awareness of individual on a five-point Likert scale (18 questions).

Section C: Availability and reliability of information on halal food products (9 questions).

Section D: Factors impacting the choice of halal food products (9 questions).

Section E: Halal food product information sources (19 questions).

Section B and Section C describe the agreement level of the respondents on a five-point Likert scale, ranging from strongly disagree to strongly agree. Section D (D1-D7) and Section E (E6-E19) describe the respondent's importance of the factors when selecting halal food product on a five-point Likert scale, ranging from Not at all important to very important. Finally, Section D (D8, D9) and Section E (E1E5) describe the respondents' frequency in using information sources on a five-point Likert scale, ranging from, Never to Always. 


\section{FINDINGS}

Descriptive analysis, Chi-square test for association and regression analysis were used to investigate the relationships between the four independent variables, namely: Attitude, Habit, Awareness of individual and Sources of information, while the dependent variables were Perception of wholesomeness of halal food among respondents.

\section{A. Respondents' Demographic Information}

As shown in Table 1, most of the respondents or 64 percent (32) of respondents are within the age of 18-24 years old. Besides that, 58 percent (29) are female. In terms of education, most of the respondents or 74 percent (37) are university level. Furthermore, private sector respondents are 10 percent (5), followed by 14 percent ( 7 respondents) are public sector while the self-employed are 12 percent $(6$ respondents) and lastly unemployed is 2 percent (one respondent). The majority of respondents are students who form 74 percent (37 respondents). Most of the respondents live in urban areas ( 82 percent or 41 respondents), while 18 percent (9 respondents) live in suburban areas. Almost half of the respondents or 52 percent (26 respondents) have monthly incomes of less than RM1000 followed by 28 percent (14 respondents) having monthly incomes between RM1000 - 3000 and lastly only 6 percent (three respondents) having monthly incomes of more than RM5000.

Table I. Respondents' demographic $(\mathbf{N}=\mathbf{5 0})$

\begin{tabular}{|c|c|c|c|}
\hline \multicolumn{2}{|c|}{ Demographic information } & Pct. & Freq. \\
\hline \multirow{2}{*}{ Gender } & Male & $42 \%$ & 21 \\
\hline & Female & $58 \%$ & 29 \\
\hline \multirow{6}{*}{ Age (yrs.) } & $18-24$ & $64 \%$ & 32 \\
\hline & $25-31$ & $14 \%$ & 7 \\
\hline & $32-38$ & $8 \%$ & 4 \\
\hline & $39-45$ & $2 \%$ & 1 \\
\hline & $46-52$ & $10 \%$ & 5 \\
\hline & 53 and above & $2 \%$ & 1 \\
\hline \multirow{5}{*}{ Education } & No formal level & $2 \%$ & 1 \\
\hline & School level & $4 \%$ & 2 \\
\hline & $\begin{array}{l}\text { Pre-university } \\
\text { level }\end{array}$ & $6 \%$ & 3 \\
\hline & University level & $74 \%$ & 37 \\
\hline & Higher level & $14 \%$ & 7 \\
\hline \multirow{5}{*}{ Occupation } & Student & $62 \%$ & 31 \\
\hline & Unemployed & $2 \%$ & 1 \\
\hline & Public sector & $14 \%$ & 7 \\
\hline & Private sector & $10 \%$ & 5 \\
\hline & Self-employed & $12 \%$ & 6 \\
\hline \multirow{2}{*}{$\begin{array}{c}\text { Residential } \\
\text { area }\end{array}$} & Urban & $82 \%$ & 41 \\
\hline & Suburban & $18 \%$ & 9 \\
\hline \multirow{4}{*}{$\begin{array}{l}\text { Monthly } \\
\text { Income } \\
(\mathrm{RM})\end{array}$} & Less than 1000 & $52 \%$ & 26 \\
\hline & $1000-3000$ & $28 \%$ & 14 \\
\hline & $3000-5000$ & $14 \%$ & 7 \\
\hline & More than 5000 & $6 \%$ & 3 \\
\hline
\end{tabular}

\section{B. Respondents' attitude variations towards halal food}

Respondents were asked to state their level of agreement towards attitude of halal food through 11 questions. For example, "Eating halal food is important for me". 98 percent $(n=49)$ strongly agreed with this statement and only two percent $(n=1)$ agreed with this statement. As another example: "Halal food is healthy". 82 percent (41) respondents strongly agreed with this statement, 12 percent (6) respondents agreed and only 6 percent (3) respondents were unsure, as shown in Table 2.

Table II. Attitude's variation towards halal food, where SA: Strongly Agree, A: Agree, N: Neutral

\begin{tabular}{|l|l|l|l|}
\hline \multirow{2}{*}{ Statement } & \multicolumn{4}{|l|}{ Level of Agreement } \\
\cline { 2 - 4 } & SA & A & N \\
\hline $\begin{array}{l}\text { Eating halal food is } \\
\text { important for me }\end{array}$ & 49 & 1 & - \\
\hline Halal food is healthy & 41 & 6 & 3 \\
\hline
\end{tabular}

C. Respondents' Habit variations in consuming halal food

Respondents were asked to state their level of agreement of their Habit in consuming halal food through three questions, for example: "I eat halal food because I am used to it". 78 percent (39) of respondents strongly agreed that consuming halal food is a habit for them, 12 percent (6) of respondents agreed with this statement, 4 percent (2) of respondents disagreed with this statement, 2 percent (1) of respondents strongly disagreed with this statement, and finally 4 percent (2) of respondents were unsure of their answer. Table 3 shows the above-mentioned results.

Table III. Habit variations in consuming halal food, where D: Disagree, SD: Strongly Disagree.

\begin{tabular}{|l|l|l|l|l|l|}
\hline \multirow{2}{*}{ Statement } & \multicolumn{5}{|c|}{ Level of Agreement } \\
\cline { 2 - 6 } & SA & A & D & SD & N \\
\hline $\begin{array}{l}\text { I eat halal food because I } \\
\text { am used to it }\end{array}$ & 39 & 6 & 2 & 1 & 2 \\
\hline
\end{tabular}

D. Respondents' awareness variations towards consuming halal food

Respondents were asked to state their level of agreement of their Awareness in consuming halal food through four questions. For example, "I will make sure that the food is halal before I consume it". 88 percent (44) of respondents strongly agreed that they have awareness in consuming halal food, 8 percent (4 respondents) agreed that they have awareness in consuming halal food, 2 percent ( 1 respondent) disagreed that he/she has awareness in consuming halal food, 2 percent (1 respondent) strongly disagreed that he has awareness in consuming halal food. These results are shown in Table 4.

Table IV. Individual's awareness variations towards consuming halal food.

\begin{tabular}{|l|l|l|l|l|}
\hline \multirow{2}{*}{ Statement } & \multicolumn{4}{|l|}{$\begin{array}{l}\text { Level } \\
\text { Agreement }\end{array}$} \\
\cline { 2 - 5 } & SA & A & D & SD \\
\hline $\begin{array}{l}\text { I will make sure that the food } \\
\text { is halal before I consume it }\end{array}$ & 44 & 4 & 1 & 1 \\
\hline
\end{tabular}

Published By: 


\section{RELATIONSHIPS BETWEEN HUMAN ATTRIBUTES AND SOURCES OF INFORMATION FOR SEEKING HALAL FOOD INFORMATION: A PILOT RESEARCH ON KUALA LUMPUR, MALAYSIA}

\section{E. Hypotheses Testing}

The three hypotheses were tested using Chi-square test for association using SPSS to discover if there is a relationship between information sources used for searching halal food information and the three independent variables: Attitude, Habit and Awareness of individual. The tests were conducted through the observed variables in the survey as follows:

\section{E.1 Relations between attitude of consumer and information sources used for halal food products}

The Chi-square test of association between the observed variable of attitude (B7, B9, B15) as independent variables and the observed variables of sources of information $(\mathrm{C} 2$, E1, C5) as dependent variables revealed that:

- $\quad$ B7 \& C2: Chi square test $X(9)=65.815$, sig. $=0$ .000 , phi $=1.147$, Cramer's V $=0.662$, contingency coefficient $=0.754$. This finding means that there is a statistically significant relationship between the goodness of halal food tastes and searching for halal food information from official sources such as TV, radio, newspaper and JAKIM among the study's respondents.

- $\quad$ B9 \& E1: Chi square $X(6)=31.371$, sig. $=0.000$, Phi $=0.792$, Cramer's $V=0.560$, contingency coefficient $=0.621$. This finding means that the agreement level of the statement "Halal food is healthy" is statistically significant with the frequency in using internet websites for searching halal food information among these study respondents.

- B15 \& C5: Chi-square $X(12)=58.750$, sig. $=0.000$, $\mathrm{Phi}=1.084$, Cramer's V=0.626, contingency coefficient $=0.735$. This finding means that the level of agreement of the statement "I will eat only halal food" is statistically significant with the level of agreement of the statement "I search for halal food information using social media, or asking family members or friends.

E.2 Relations between habit of consumer and information sources used for halal food products

The Chi-square test of association between the observed variable of Habit (B14, B18) as independent variables and the observed variables of sources of information $(\mathrm{C} 2, \mathrm{C} 5$, E2) as dependent variables revealed that:

- B14 \& C2: Chi-square test X (12) = 33.424, Sig. = 0.001 , Phi $=0.818$, Cramer's V $=0.472$, contingency coefficient $=0.633$. This finding means that the agreement level of the statement "I will eat only at the halal food places" is statistically significant with the agreement level of a statement "I search for halal food products from official sources such as TV, radio, newspaper and JAKIM".

- B14 \& C5: Chi-square test of association X (12) $=36.657$, Sig. $=0.000$, Phi $=0.856$, Cramer's V= 0.494 , contingency coefficient $=0.650$. This finding means that there is a statistically significant relationship between the observed variable of Habit "I will eat only at halal food places" and I search for halal food information using social media, or asking family members or friends.

- B18 \& E2: Chi-square test $X(8)=16.057$, Sig. $=0.042$, $\mathrm{Phi}=0.567$, Cramer's V $=0.401$. this finding means that the agreement among the study respondents with looking at the ingredients when they purchase food products is statistically significant with the frequency in using Mass Media (TV, radio and newspaper).

E.3 Relations between awareness of consumer and information sources used for halal food product Relations

The Chi-square test of association between the observed variable of Awareness of consumer B12 as independent variable and the observed variables of sources of information (C5, E1) as dependent variables revealed that:

- B12 \& C5: Chi-square test of association X (9) 22.339, Sig. $=0.008$, Phi $=0.668$, Cramer's V= 0.386 , Contingency coefficient $=0.556$. This finding means that there is a statistically significant relationship between the observed variable of awareness of consumer represented by the statement: "I eat halal food because it is part of my identity as a Muslim" and the observed variable of sources of information represented by the statement: "I search for halal food information using social media, or asking family members and friends".

- B12 \& E1: Chi-square test of association X (9) = 18.746, Sig. $=0.027$, Phi $=0.612$, Cramer's V=0.354, Contingency coefficient $=0.522$.This finding means that there is a statistically significant relationship between the observed variable of awareness of consumer represented by the statement: "I eat halal food because it is part of my identity as a Muslim" and the observed variable of sources of information represented by the frequency in using internet websites for searching halal food information among the study respondents.

Furthermore, the three hypotheses were tested using linear regression analysis to predict the dependent variable: "Perception of wholesomeness of halal food", represented by E17 and E19 based on the observed variables of attitude, habit and awareness of individual that were statistically significant with observed variables of information sources above, using a Chi-square test. The results reveal that:

- Attitude of consumer represented by the observed variable B7: "Halal food tastes good" which is statistically significant with the information sources used represented by the observed variables C2: "I search for halal food products from official sources", as indicated in section 5.5.1, positively influences the consumer perception of wholesomeness of halal food represented by the observed variable E19: "the importance of halal zeros' concept which means that no haram material used in the production assurance system" (B7: $\mathrm{p}=.034$ which is $<.05)$. Therefore, the hypothesis one is accepted. The $\mathrm{R}$ square of 0.292 indicates that 29.2 percent of the variations of respondents indicate the importance of halal zeros' concept could be explained by their variations in agreement towards the goodness of halal food taste. 
- Habit of consumer in searching for halal food information represented by: (B14, B18) which is statistically significant with the information sources used represented by the observed variables: C2, C5, $\mathrm{E} 2$ as indicated by section 5.5.2, positively influences the consumer perception wholesomeness of halal food represented by the observed variable of wholesomeness E17: "The importance of halal assurance system" (B14: $p=0.001, B 18: p=0.032$ which both values are <.05). Therefore, the hypothesis two is accepted. The $\mathrm{R}$ square of 0.342 indicates that 34.2 percent of the variations of respondents in indicating the importance of halal assurance system in searching for halal food information could be explained by their variations of attitude in eating only at halal food places, alongside their variations in looking at the ingredients of the halal product before they purchase it.

- Awareness of consumers in searching for halal food information represented by the observed variable B12: "I eat halal food because it is part of my identity as a Muslim" which is statistically significant with the information sources used represented by the observed variables: C5, E2 as indicated in section 5.5.3, positively influences the consumer perception wholesomeness of halal food represented by the assurance system" (B12: $\mathrm{p}=0.000$, which is <.05). Therefore, the hypothesis three is accepted. The $\mathrm{R}$ square of 0.341 indicates that 34.1 percent of the variations of respondents in indicating the importance of a halal assurance system in searching for halal food information could be explained by the variations of awareness of respondents in eating halal food because it is part of their identity as Muslims.

\section{DISCUSSION \& RESULTS}

The main purpose of this paper is to investigate the effects of linking human attributes namely: Attitude, Habit and awareness of individual with information sources used in searching for halal food information product effectively. A survey was conducted to answer the following research questions:

a) Are there any relationships between the use of different information sources and Attitude that might be positively used and related to the perception of wholesomeness which leads to effective seeking for halal food information?

The findings of this study showed that there is a statistically significant relationship between the respondents' agreement in stating the goodness of halal food and the respondents' agreement in searching about halal food information products from official sources such as TV, radio, newspaper and Malaysian Islamic Development department publications (JAKIM). This relationship positively influences the respondents' perception of wholesomeness of halal food by the variations of respondents in determining the importance of halal zero's concept which means that no haram material was used in the production assurance system to search for halal food information. This finding is consistent with the findings of observed variable E17: "The importance of halal

[12] who revealed that attitude positively influences the behavioral intention in consuming halal food.

b) Are there any relationships between the use of different information sources and Habit that might be positively used and related to the perception of wholesomeness which leads to effective seeking for halal food information?

There is a statistically significant relationship between the respondents' agreement in eating only at halal food places and the respondents' agreement in searching for halal food information products from official sources such as TV, radio, newspaper and Malaysian Islamic Development department publications (JAKIM), along with social media, family members and friends. As such, there is a statistically significant relationship between the respondents' agreement in not looking at the ingredients when they purchase food products and the respondents' frequency in using mass media (T.V., radio, newspaper). These two relationships positively influence the respondent perception of wholesomeness of halal food respondents by the variations of respondents in determining the significance of halal assurance systems to search for halal food information. This finding is consistent with [14] who have described how eating halal meat can be considered as a norm or a habit for some Muslims because this is their identity.

c) Are there any relationships between the use of different information sources and Awareness of individual that might be positively used and related to the perception of wholesomeness which leads to effective seeking for halal food information?

Respondents' agreement in eating halal food being part of their identity as Muslims has a statistically significant relationships with both respondents' agreement in searching for halal food information using social media, and the frequency in using internet websites among respondents. These two relationships positively influence the respondents' perception of wholesomeness of halal food represented by the variations of respondents in determining the importance of a halal assurance system to search for halal food information. This finding is in line with [11] who found that Muslim families have high levels of awareness towards halal food products

\section{VII.CONCLUSION AND FUTURE WORK}

This research is one such contribution that has looked into the deeper aspects of human attributes, along with information seeking attributes by linking human attributes, namely: attitude, habit and awareness of individual with the information seeking attribute of information sources. This linking might be related to the perception of wholesomeness of the halal food products; for guiding the process of information seeking behavior for halal food products among Malaysian Muslim consumers.

The major findings of this study are the variations of agreement towards attitude, habit, awareness of individual and information sources used, both formal and informal, for searching halal food products among Malaysian Muslim consumers. These variations among Malaysian Muslim 


\section{RELATIONSHIPS BETWEEN HUMAN ATTRIBUTES AND SOURCES OF INFORMATION FOR SEEKING HALAL FOOD INFORMATION: A PILOT RESEARCH ON KUALA LUMPUR, MALAYSIA}

consumers determine the relationships between human and information seeking attributes so that we reach to the perception of wholesomeness of halal food products and hence for effective searching process for halal food information among Malaysian Muslim consumers.

This study ensures the perception of wholesomeness of halal food among respondents because of the usage of credible and trusted information sources to achieve their attitude, habit and awareness towards halal food.

More importantly, future research might focus on confirmation of the above relationships in other settings, for example: linking the above-mentioned human attributes in this paper with another information seeking attribute like process verification, and hence arriving to another searching process guidance for halal food products.

Due to the fact that this research is limited to Malaysian Muslim consumers, future research might consider nonMuslim consumers in Malaysia and even in other countries. Accordingly, halal food should be hygienically prepared, treated and produced so as to be healthily safe for human consumption in general.

\section{REFERENCES}

1. D. Ismoyowati, "Halal Food Marketing: A Case Study on Consumer Behavior of Chicken-Based Processed Food Consumption in Central Part of Java, Indonesia," Agriculture and Agricultural Science Procedia, vol.3, pp. 169-172, 2015.

2. Z. M. Janis, "Halal Food- Production, Preparation, Handling and Storage- General Guidelines," Malaysian Standard MS 1500 \& Quality News, pp. 2-3, 2004.

3. H. A. Talib, K. A. M. Ali, and K. R. Jamaluddin, "Quality Assurance in Halal Food Manufacturing in Malaysia: A Preliminary Study," In the Proceedings of the International Conference on Mechanical \& Manufacturing Engineering, pp. $1-5,2008$

4. N. M. N. Muhammad, F. M. Isa, and B. C. Kifli, "Positioning Malaysia as Halal-Hub: Integration Role of Supply Chain Strategy and Halal Assurance System," Asian Social Science, vol. 5 (7), pp. 44-52, 2009.

5. J. Leckie Gloria, E. Karen, Pettigrew, Christian and Sylvain, "Modelling the Information Seeking of Professionals: A General Model Derived from Research on Engineers, Health Care Professionals and Lawyers," Library Quarterly vol. 66(2), pp. 161-193, 1996.

6. L. Freund, "Contextualizing the Information Seeking Behavior of Software Engineers," Journal of Association for Information Science and Technology, vol. 66(8), pp. 1594$1605,2015$.

7. T. D. Wilson, "Models in Information Behavior Research," Journal of Documentation, vol. 55(3), pp. 249-270, 1999 a.

8. G. Marchionini, "Information Seeking in Electronic Environments," New York: Cambridge University Press, 1995.

9. I. Ajzen, "From Intention to Action: A Theory of Planned Behavior in J. Kuhl, and J. Beckman," (Eds), Action Control: From Cognition to Behavior, Springer New York, NY, 1985.

10. I. Ajzen, "The Theory of Planned Behavior," Organizational Behavior and Human Decision Processes vol. 50, pp. 179211, 1991.

11. S. Z. Yusoff and N. A. Adzharuddin, "Factor of Awareness in Searching and Sharing of Halal Food Product Among Muslim Families in Malaysia," SHS Web Conferences 33, 00075 iCOME 16, 2017.

12. A. Abdul Khalek, S. Hayaati, S. I. Hairunnisa, and M. Ibrahim, "A Study on The Factors Influencing Young Muslims' Behavioral Intention in Consuming Halal Food in Malaysia," Shariah Journal, vol. 23, pp. 79-102, 2015.
13. M. Borzooei and M. Asgari, "The Halal Brand Personality and its Effect on Purchase Intention," Interdisciplinary Journal of Contemporary Research in Business, vol. 5(3), 481-491, 2013.

14. K. Bonne, I. Vermeir, F. Bergeaud-Blackler, and W. Verbeke, "Determinants of halal meat consumption in France," British Food Journal, vol. 109(5), pp. 367-386, 2007. 